\title{
PERAN BADAN PERTANAHAN NASIONAL KOTA SAMARINDA DALAM PENYELESAIAN SENGKETA PERTANAHAN (DITINJAU BERDASARKAN PERATURAN KEPALA BADAN PERTANAHAN NASIONAL NOMOR 3 TAHUN 2011 TENTANG PENGELOLAAN PENGKAJIAN DAN PENANGANAN KASUS PERTANAHAN)
}

\author{
Gita Fitriana dan Abdul Mukmin Rehas \\ nagita.fitri@gmail.com,mukmin@uwgm.ac.id \\ Fakultas Hukum Universitas Widya Gama Mahakam Samarinda
}

\begin{abstract}
ABSTRAK
Tanah merupakan sumber daya yang menopang kehidupan manusia tidak jarang dengan kedudukan tanah yang sangat penting menyebabkan sengketa tanah antar manusia, oleh karena itu Badan Pertanahan Nasional Kota Samarinda berperan dalam membantu penyelesaian sengketa secara damai untuk kepentingan kedua belah pihak yang bersengketa. Peran Badan Pertanahan Nasional Kota Samarinda dalam menangani dan menyelesaikan sengketa pertanahan diatur dalam Peraturan Kepala Badan Pertanahan Nasional Republik Indonesia Nomor 3 Tahun 2011 Tentang Pengelolaan Pengkajian dan Penanganan Kasus Pertanahan. Mekanisme penyelesaian sengketa oleh Badan Pertanahan Nasional harus mengedepankan mediasi yang bertujuan untuk mencapai keputusan mufakat dan tidak merugikan para pihak. Namun dalam menjalankan tugasnya dalam menangani sengketa pertanahan di Kota Samarinda, tidak jarang terjadi kendala-kendala yang harus dihadapi oleh Badan Pertanahan Nasional Kota Samarinda.
\end{abstract}

Kata Kunci : Peran, Badan Pertanahan Nasional, Penyelesaian Sengketa, Tanah

\section{ABSTRACT}

Land is a resource that substains human life but with the importance of land in human life often causing disputes between people, therefore The Samarinda Land National Agency have a role for helping resoluting disputes between the parties with considering the interest of parties that in dispute. The role of The Samarinda National Land Agency in addressing and resolving land disputes, stipulated in the Regulation of The National Land Agency of The Republic of Indonesia Number 3 of 2011 Concerning The Assessment and Management of Land Case Handling. Mechanism for dispute resolution by The Samarinda National Land Agency must prioritize mediation aimed at reaching consesus decisions and not detrimental to the parties. But in carrying out its duties dealing with land disputes in Samarinda, there is always obstacles that must be faced by The Samarinda National Land Agency.

\section{Keywords : Role, Samarinda National Land Agency, Dispute Resolution, Land}

\section{BAB I \\ PENDAHULUAN}

\section{A. Latar Belakang Masalah}

Tanah merupakan sumber kehidupan bagi makhluk hidup baik manusia, hewan dan tumbuh-tumbuhan. Manusia hidup dan tinggal di atas tanah dan memanfaatkan tanah untuk sumber kehidupan dengan menanam tumbuh-tumbuhan yang menghasilkan makanan. Mengingat begitu pentingnya tanah merupakan sebuah aset yang sangat penting dalam kehidupan bermasyarakat berbangsa dan bernegara karena dapat menghasilkan sumber daya alam yang sangat bermanfaat oleh karena itu pengelolaan dan pemanfaatan tanah harus diperhatikan sehingga sesuai dengan prinsip Undang - Undang Dasar Negara Republik Indonesia Tahun 1945 Pasal 33 ayat (3). 
Menurut Undang-Undang Dasar 1945 Pasal 33 ayat 3 berbunyi : "Bumi dan air dan kekayaan alam yang terkandung di dalamnya dikuasai oleh negara dan dipergunakan untuk sebesar-besar kemakmuran rakyat". Oleh karena itu, sudah semestinya pemanfaatan fungsi bumi dan air, dan kekayaan yang terkandung di dalamnya adalah ditujukan untuk mencapai sebesar-besarnya kemakmuran seluruh rakyat Indonesia." 1

Sedangkan menurut pasal 2 ayat (2) Undang-Undang Nomor 5 Tahun 1960 Tentang Pokok-pokok Agraria yang berbunyi : "Hak menguasai dari negara memberi wewenang untuk :

1. Mengatur dan menyelenggarakan peruntukan, penggunaan, persediaan, dan pemeliharaan bumi, air dan ruang angkasa;

2. Menentukan dan mengatur hubunganhubungan hukum antara orang-orang dengan bumi, air dan ruang angkasa;

3. Menentukan dan mengatur hubunganhubungan hukum antara orang-orang dengan perbuatan-perbuatan hukum mengenai bumi, air dan ruang angkasa." 2

Berdasarkan hak menguasai negara sebagaimana di atas dan mengingat begitu pentingnya tanah bagi manusia, maka penguasaan atas tanah diatur UndangUndang Nomor 5 Tahun 1960 Tentang Pokok-pokok Agraria (UUPA) yang kemudian ditentukan macam-macam hak atas permukaan bumi, yang disebut tanah, yang dapat diberikan kepada dan dipunyai oleh orang-orang baik sendiri maupun bersama-sama dengan orang-orang lain serta badan hukum.

Negara Indonesia merupakan salah satu negara agraris, dimana tanah merupakan salah satu sumber daya alam yang sangat penting bagi kehidupan manusia karena tanah selain memiliki nilai ekonomis, juga mempunyai nilai filosofis. Namun, seiring dengan berjalannya waktu

\footnotetext{
${ }^{1}$ Muchsin, Imam Koeswahyono, Soimin, Hukum Agraria Indonesia Dalam Perspektif Sejarah, Refika Aditama, Bandung, 2010, Hal. 39

${ }^{2}$ Ibid, Halaman 40
}

yang disertai dengan berkembangnya suatu masyarakat, dimana tanah tidak hanya digunakan sebagai tempat bermukim namun digunakan juga sebagai sarana dalam melaksanakan kegiatan usaha sehingga tidak jarang menyebabkan sengketa pertanahan. Sengketa tanah yang muncul akhir-akhir ini, semakin kompleks. Pemicunya, tak sebatas aspek ekonomi saja, melainkan sosial dan budaya bahkan juga agama. ${ }^{3}$

Hampir separuh penduduk Indonesia menggantungkan jalannya roda perekonomian mereka disektor pertanahan, baik dalam skala kecil, menengah bahkan dalam skala besar. Sementara kondisi tata kota di Indonesia ini sering berubah-ubah sehingga banyak menyebabkan masalah pertanahan, dengan hal ini bertambahnya juga penduduk Indonesia. Dengan kondisi yang ada, banyak sekali bermunculan kasus-kasus sengketa tanah. Dengan Undang-Undang Pertanahan yang ada, diharapkan sengketa mengenai tanah dapat dicegah, paling tidak dapat diminimalkan. Menurut Rinto Manulang untuk itu Pemerintah yang diwakili oleh instansi yang berwenang mengadakan dan menyelenggarakan administrasi pertanahan. ${ }^{4}$

Timbulnya sengketa hukum mengenai tanah berawal dari pengaduan suatu pihak (orang atau badan hukum) yang berisi keberatan-keberatan dan tuntutan hak atas tanah baik terhadap status tanah, prioritas maupun kepemilikannya dengan harapan dapat memperoleh penyelesaian secara administrasi sesuai dengan ketentuan peraturan yang berlaku.

Khususnya di bidang pertanahan, instansi atau lembaga yang diberikan kewenangan oleh negara untuk pengaturan dan pengelolaan dibidang pertanahan adalah Badan Pertanahan Nasional atau disingkat BPN hal ini tertuang dalam

\footnotetext{
${ }^{3}$ Herwandi, Peran Kantor Pertanahan Dalam Rangka Penyelesaian Sengketa Tanah Secara Mediasi Di Kantor Pertanahan Jakarta Utara, Tesis, Program Magister Kenotariatan Universitas Diponegoro, Semarang, 2010, Hal. 2

${ }^{4}$ Rinto Manulang, Segalanya Hal Tentang Tanah, Rumah Dan Perizinannya,Buku Pintar, Yogyakarta, 2012. Hal. 5
} 
Peraturan Presiden Nomor 20 Tahun 2015 Tentang Badan Pertanahan Nasional. Secara garis besar Badan Pertanahan Nasional (BPN) adalah Lembaga Pemerintah Non Departemen yang berada di bawah dan bertanggung jawab kepada Presiden (Pasal 1 ayat (1) Peraturan Presiden Nomor 20 Tahun 2015 tentang Badan Pertanahan Nasional).

Selanjutnya dalam Pasal 2 Peraturan Presiden Nomor 20 Tahun 2015 dijelaskan bahwa Badan Pertanahan Nasional mempunyai tugas melaksanakan tugas pemerintah di bidang pertanahan sesuai dengan ketentuan peraturan perundangundangan. Dalam melaksanakan tugas sebagaimana dimaksud Pasal 2 Peraturan Presiden 20 Tahun 2015 dijelaskan juga yang menjadi kewenangan BPN dalam menjalankan tugasnya diatur dalam Pasal 3 Peraturan Presiden 20 Tahun 2015.

Tugas sebagaimana yang dimaksud pasal 2 diatas dijelaskan juga sebagaimana di dalam Pasal 3 Peraturan Presiden 20 Tahun 2015, Badan Pertanahan Nasional menyelenggarakan fungsi yaitu :

a. penyusunan dan penetapan kebijakan di bidang pertanahan;

b. perumusan dan pelaksanaan kebijakan di bidang survei;

c. perumusan dan pelaksanaan kebijakan di bidang penetapan hak tanah, pendaftaran tanah, dan pemberdayaan masyarakat;

d. perumusan dan pelaksanaan kebijakan di bidang pengaturan, penataan, dan pengendalian kebijakan pertanahan;

e. perumusan dan pelaksanaan kebijakan di bidang pengadaan tanah;

f. perumusan dan pelaksanaan kebijakan di bidang pengendalian dan penanganan sengketa dan perkara pertanahan;

g. pengawasan atas pelaksanaan tugas di lingkungan Badan Pertanahan Nasional;

h. pelaksanaan koordinasi tugas, pembinaan, dan pemberian dukungan administrasi kepada seluruh unit organisasi di lingkungan Badan Pertanahan Nasional;

i. pelaksanaan pengelolaan data informasi lahan pertanian pangan berkelanjutan dan informasi di bidang pertanahan;

j. pelaksanaan penelitian dan pengembangan di bidang pertanahan; dan

k. pelaksanaan pengembangan sumber daya manusia di bidang pertanahan.

Selain fungsi tersebut di atas Badan Pertanahan Nasional juga memiliki tugas untuk menyelesaikan kasus sengketa pertanahan antara para pihak perorangan, yang mengajukan pengaduan kepada Badan Pertanahan Nasional untuk penyelesaian sengketa diluar pengadilan agar meminimalisir gugatan sehingga para pihak tidak perlu melakukan penyelesaian melalui lembaga peradilan negeri. Tugas Badan Pertanahan Nasional ini diatur dalam Peraturan Kepala Badan Pertanahan Nasional Nomor 3 Tahun 2011 tentang Pengelolaan Pengkajian dan Penanganan Kasus Pertanahan.

Saat ini khususnya permasalahan atau sengketa pertanahan oleh masyarakat dipahami hanya dapat di selesaikan melalui jalur Litigasi (Peradilan), sangat sedikit masyarakat khususnya di Kota Samarinda yang mengerti adanya fasilitas penyelesaian sengketa pertanahan melalui jalur non litigasi (di luar Pengadilan) atas prakarsa Badan Pertanahan Nasional sehingga hal inilah yang menarik buat penulis untuk mengkaji permasalahan tersebut.

\section{B. Rumusan Masalah}

1. Bagaimana mekanisme penyelesaian sengketa pertanahan yang dilakukan Badan Pertanahan Nasional Kota Samarinda berdasarkan Peraturan Kepala Badan Pertanahan Nasional Republik Indonesia Nomor 3 Tahun 2011 Tentang Pengelolaan Pengkajian dan Penanganan Kasus Pertanahan?

2. Apa saja kendala Badan Pertanahan Nasional Kota Samarinda dalam menyelesaikan sengketa pertanahan berdasarkan Peraturan Kepala Badan Pertanahan Nasional Republik Indonesia Nomor 3 Tahun 2011 Tentang Pengelolaan Pengkajian dan Penanganan Kasus Pertanahan? 


\section{Tujuan Dan Manfaat Penelitian}

Adapun tujuan dari penelitian ini adalah Untuk mengetahui dan menganalisa mekanisme penyelesaian sengketa pertanahan yang dilakukan Badan Pertanahan Nasional Kota Samarinda, serta kendala apa saja yang ditemukan dalam penyelesaian mekanisme tersebut.

Adapun dalam penelitian ini diharapkan bermanfaat tidak hanya untuk penulis melainkan bermanfaat baik untuk masyarakat bahwa Hasil penelitian ini diharapkan dapat memberikan pengetahuan, wawasan serta pencerahan kepada masyarakat luas sehingga dapat dijadikan pedoman untuk masyarakat apabila mengalami masalah tanah dan mengetahui langkah-langkah Badan Pertanahan Nasional dalam penyelesaian sengketa pertanahan tersebut. Untuk pemerintah sendiri diharapkan untuk memberikan masukan kepada Badan Pertanahan Nasional dalam menyelesaikan sengketa pertanahan tersebut. Sekaligus sebagai sumbangan pemikiran dalam pengembangan kebijakan terhadap penyelesaian sengketa oleh Badan Pertanahan Nasional. Dan bagi Akademisi Hasil penelitian ini diharapkan dapat memberikan manfaat bagi perkembangan hukum agraria, serta dapat memberi sumbangan bagi penelitian pada dunia pendidikan, khususnya Perguruan Tinggi. Setelah membaca tugas akhir ini diharapkan pembaca mengetahui dan memahami latar belakang tentang peran Badan Pertanahan Nasional Kota Samarinda dalam penyelesaian sengketa.

\section{METODE PENELITIAN}

\section{A. Jenis Penelitian}

Jenis Penelitian yang digunakan dalam penelitian ini adalah yuridis normatif yaitu suatu penelitian yang memerlukan data agar dapat membantu penelitian itu sendiri.

\section{B. Sumber Data}

Bahan Hukum Primer, yaitu bahan hukum yang bersifat mengikat yang terdiri dari :
1) Undang-Undang Dasar Negara Republik Indonesia Tahun 1945 Amandemen IV

2) Undang-Undang Nomor 5 Tahun 1960 Tentang Peraturan Dasar Pokok-Pokok Agraria (UUPA)

3) Undang-Undang Republik Indonesia Nomor 30 Tahun 1999 Tentang Arbitrase dan Alternatif Penyelesaian Sengketa

4) Peraturan Presiden Republik Indonesia Nomor 20 Tahun 2015 Tentang Badan Pertanahan Nasional

5) Peraturan Kepala Badan Pertanahan Badan Pertanahan Nasional Republik Indonesia Nomor 4 Tahun 2006 Tentang Organisasi dan Tata Kerja Kantor Wilayah Badan Pertanahan Nasional dan Kantor Pertanahan

6) Peraturan Kepala Badan Pertanahan Nasional Republik Indonesia Nomor 3 Tahun 2011 Tentang Pengelolaan Pengkajian dan Penanganan Kasus Pertanahan

7) Keputusan Kepala Badan Pertanahan Nasional Republik Indonesia Nomor 34 Tahun 2007 Tentang Petunjuk Teknis Penanganan dan Penyelesaian Permasalahan Pertanahan

Bahan Hukum Sekunder, yaitu bahan hukum yang memberi petunjuk dan kejelasan terhadap bahan hukum primer, yang terdiri dari buku-buku, makalah, artikel, hasil penelitian karya ilmiah lainnya yang berhubungan dengan penelitian ini.

Bahan Hukum Tersier, yaitu bahan hukum yang diperoleh melalui studi kepustakaan, sesuatu yang dapat menjelaskan dari apa yang menjadi penelitian yang terdapat pada sumber hukum primer atau sumber hukum sekunder, seperti kamus bahasa Indonesia, kamus hukum yang berhubungaan dengan permasalahan yang menjadi objek penelitian dalam penulisan ini.

\section{Teknik Pengumpulan Data}

Pengumpulan Data yang dilakukan dalam penelitian ini melalui 2 (dua) cara, yakni melalui studi kepustakaan dan wawancara dengan Narasumber terkait dalam penelitian ini. 


\section{Lokasi Penelitian}

Adapun lokasi atau tempat penelitian yang akan penulis teliti guna melengkapi data-data yaitu di Kantor Pertanahan Kota Samarinda yang beralamat di Jalan Dahlia Nomor 3 Samarinda, Kalimantan Timur.

\section{E. Analisis Data}

Analisis data yaitu menguraikan data dalam bentuk rumusan angka-angka sehingga mudah dibaca dan diberi arti bila data itu kuantitatif, menguraikan data dalam bentuk kalimat yang baik dan benar, sehingga mudah dibaca dan diberi arti (diinterpretasikan) bila data ini kualitatif. Metode analisis data yang digunakan dalam penelitian ini adalah deskriptif kualitatif yaitu menganalisis dan memberikan gambaran dari data hasil observasi dan wawancara.

\section{PEMBAHASAN}

\section{A. Mekanisme Penyelesaian Sengketa Pertanahan Yang Dilakukan Badan Pertanahan Nasional Kota Samarinda Ditinjau Berdasarkan Perkaban Nomor 3 Tahun 2011 Tentang Pengelolaan Pengkajian dan Penanganan Kasus Pertanahan}

Ada berbagai jalur yang dapat ditempuh oleh para pihak yang bersengketa untuk mendapatkan solusi sengketa pertanahan. Salah satu bentuk jalur yang dapat ditempuh oleh pihak yang bersengketa adalah secara non litigasi berupa penaganan kasus pertanahan melalui Kantor Badan Pertanahan Nasional. Dalam Peraturan Kepala Badan Pertanahan Nasional Nomor 3 Tahun 2011 Tentang Pengelolaan Pengkajian dan Penanganan Kasus Pertanahan, merupakan tugas dari Badan Pertanahan Nasional melalui Kepala Seksi Sengketa, Konflik, dan Perkara yang merupakan pejabat di lingkungan Kantor Badan Pertanahan Nasional Kota Samarinda melalui mediasi.

Dalam penanganan kasus pertanahan oleh Badan Pertanahan Nasional di Kota Samarinda terdapat jenis atau tipologi sengketa pertanahan yaitu antara lain penguasaan dan pemilikan tanah, penetapan hak dan pendaftaran tanah, batas atau letak bidang tanah, pengadaan tanah, tanah obyek landreform, tuntutan ganti rugi tanah partikelir dan tanah ulayat/tanah adat. Untuk menangani masalah pertanahan di Kota Samarinda seperti yang disebutkan diatas, Kantor Badan Pertanahan Nasional Kota Samarinda melakukan pengkajian dan pengelolaan sebagaimana yang diatur dalam Peraturan Kepala Badan Pertanahan Nasional Republik Indonesia Nomor 3 Tahun 2011 Tentang Pengelolaan Pengkajian dan Penanganan Kasus Pertanahan. Sehingga penyelesaian sengketa pertanahan oleh Kantor Badan Pertanahan Nasional Kota Samarinda melalui mediasi terbagi menjadi beberapa tahap yang merupakan mekanisme penyelesaian sengketa pertanahan.

\section{Tahap Pertama yaitu adanya pengaduan \\ Pengaduan ini dilakukan oleh pihak} yang bersengketa kepada Kantor Badan Pertanahan Nasional Kota Samarinda berkenaan dengan sengketa tanah. Pengaduan diajukan dapat dilakukan dengan 2 cara, yaitu pengaduan secara tertulis ataupun dapat juga melalui media lisan. Setelah adanya pengaduan lalu diteruskan atau disampaikan kepada Kepala Seksi Sengketa Konflik dan Perkara Kantor Pertanahan Nasional Kota Samarinda.

\section{Tahap Kedua yaitu menelaah pengaduan (pihak yang bersengketa) \\ Kemudian persiapan untuk} mempertemukan kedua belah pihak. Halhal yang dipersiapkan yaitu :

a. Mengkaji permasalahan tersebut dapat diselesaikan secara mediasi atau tidak

b. Menentukan strategi penyelesaian perkara secara mediasi dengan mengedepankan keputusan hasil mediasi secara mufakat dan kekeluargaan

c. Pembentukan tim penanganan sengketa tentatif atau dapat juga pejabat struktural yang berwenang untuk turun langsung mengadakan mediasi

d. Penyiapan bahan, selain persiapan prosedure disiapkan bahan-bahan yang 
diperlukan untuk melakukan mediasi terhadap pokok sengketa pertanahan, resume telaahan.

e. Kemudian menentukan waktu dan tempat mediasi.

\section{Tahap Ketiga yaitu undangan atau pemanggilan}

Disampaikan kepada para pihak yang berkepentingan, instansi terkait (apabila dipandang perlu) untuk mengadakan musyawarah penyelesaian sengketa dimaksud dan diminta untuk membawa serta data atau informasi yang diperlukan. Yang kemudian untuk selanjutnya penataan struktur pertemuan dengan posisi tempat duduk huruf "U Seat" atau lingkaran.

\section{Tahap Keempat yaitu upaya mediasi}

Kegiatan mediasi disini yaitu yang harus dilakukan seorang mediator adalah mengatasi hambatan hubungan antar para pihak (hubungan personal antar pihak yang bersengketa). Dan membuat agar suasana mediasi diantara kedua belah pihak yang bersengketa tidak kaku membuat suasana akrab dan selain itu juga sebagai seorang mediator harus memberikan penjelasan tentang peran mediator, sebagai peran ketiga yang tidak memihak (berkedudukan netral), kehendak para pihak tidak dibatasi, kedudukan para pihak dan kedudukan mediator sendiri harus netral, kunci dari sesi ini adalah penegasan mengenai kesediaan para pihak untuk menyelesaikan sengketa melalui mediasi dan oleh Badan Pertanahan Nasional Kota Samarinda. Yang selanjutnya di dalam hal-hal tertentu berdasarkan kewenangannya (authoritas mediator autoritatif) mediator dapat melakukan intervensi atau campur tangan dalam proses mencari kesepakatan dari persoalan yang disengketakan oleh kedua belah pihak yang bersengketa, untuk menempatkan kesepakatan yang hendak dicapai sesuai dengan hukum pertanahan.

Kemudian klarifikasi para pihak, yaitu para pihak mengetahui kedudukannya, kedua belah pihak dengan obejektivitas penyelesaian sengketa, kedudukan, hak dan kewajiban sama, masing-masing pihak berhak memberikan dan memperoleh informasi atau data yang disampaikan oleh lawan, para pihak dapat membantah atau meminta klarifikasi dari lawan dan wajib menghormati para pihak lainnya, pengaturan pelaksanaan mediasi, dari permulaan mediasi telah disampaikan aturan-aturan mediasi yang harus dipatuhi oleh semua pihak yang terlibat di dalam mediasi, aturan tersebut inisiatif dari mediator atau disusun baru sesuai kesepakatan oleh para pihak. Dan setelah klarifikasi para pihak dilanjutkan dengan menyamakan pemahaman dan menetapkan agenda musyawarah.

Selanjutnya dengan identifikasi kepentingan yang artinya dilakukan identifikasi untuk menentukan pokok masalah sebenarnya, serta relevansi sebagai bahan untuk negosiasi. Pokok masalah harus selalu menjadi fokus proses mediasi selanjutnya. Jika terdapat penyimpangan, seorang mediator harus mengingatkan untuk kembali pada fokus permasalahan. Selain itu, kepentingan yang menjadi fokus mediasi dapat menentukan kesepakatan penyelesaian. Kepentingan ini tidak harus dilihat dari aspek hukum saja, dapat dilihat dari aspek lain sepanjang memungkinkan dilakukan negosiasi dan hasilnya tidak melanggar hukum.

Setelah identifikasi kepentingan yang dimaksud yaitu mengenai generalisasi opsiopsi para pihak atau apa yang diinginkan oleh para pihak seperti pengumpulan opsiopsi sebagai alternatif yang diminta kemudian dilakukan generalisasi alternatif tersebut sehingga terdapat hubungan antar alternatif dengan permasalahannya. Dengan generalisasi terdapat kelompok opsi yang tidak dibedakan dari siapa, tetapi bagaimana cara menyelesaikan opsi tersebut melalui negosiasi, maka proses negosiasi lebih mudah. Opsi yang dimaksud disini adalah sejumlah tuntutan dan alternatif penyelesaian terhadap sengketa dalam suatu proses mediasi. Kedua belah pihak dapat mengajukan opsi-opsi penyelesaian yang diinginkan. Selanjutnya, adalah penentuan penyelesaian sengketa dari opsi yang dipilih dan mediator bertugas untuk memilih opsi yang akan dipakai setelah adanya kesepakatan antar kedua belah pihak yang bersengketa. 
Yang terakhir dari tahap upaya mediasi disini adalah negosiasi akhir yang dimana para pihak yang bersengketa melakukan negosiasi final yaitu klarifikasi ketegasan mengenai opsi-opsi yang telah disepakati bagi penyelesaian sengketa yang dimaksud. Hasil dari tahap ini adalah putusan penyelesaian sengketa yang merupakan kesepakatan para pihak yang bersengketa. Kesepakatan tersebut pada pokoknya berisi opsi yang diterima serta hak dan kewajiban dari para pihak. Penegasan/klarifikasi ini diperlukan agar para pihak tidak ada keraguan lagi akan pilihannya untuk menyelesaikan sengketa tersebut.

\section{Tahap Kelima yaitu formalisasi kesepakatan penyelesaian sengketa Yaitu dirumuskan dalam bentuk} kesepakatan atau agreement atau perjanjian, dengan kesepakatan tersebut secara substansi mediasi telah selesai, setiap kegiatan mediasi hendaknya dituangkan dalam berita acara mediasi, hasil mediasi dilaporkan kepada pejabat yang berwenang untuk ditindak lanjuti sesuai dengan peraturan yang berlaku, formalisasi kesepakatan secara tertulis dengan menggunakan format perjanjian, yang kemudian dalam setiap mediasi perlu dibuat laporan hasil mediasi yang berlangsung agar mempunyai kekuatan mengikat, berita acara tersebut ditanda tangani oleh para pihak, mediator dan saksi-saksi.

Menurut analisa penulis mekanisme penyelesaian sengketa oleh Badan Pertanahan Nasional, sebagaimana yang telah diteliti di Kantor Pertanahan Kota Samarinda belum dijalankan secara maksimal sesuai Peraturan Kepala Badan Pertanahan Nasional Republik Indonesia Nomor 3 Tahun 2011 Tentang Pengelolaan Pengkajian dan Penanganan Kasus Pertanahan. Hal ini disebabkan karena adanya beberapa kendala yang akan penulis uraikan, dalam pembahasan dibawah ini.

\section{B. Kendala Badan Pertanahan Nasional Kota Samarinda Dalam Menyelesaikan Pertanahan}

Kewenangan penyelesaian sengketa pertanahan pada prinsipnya merupakan kewenangan yang diberikan atau melekat di instansi Badan Pertanahan Nasional. Penyelesaian sengketa pertanahan melalui jalur Badan Pertanahan Nasional (non litigasi) merupakan alternatif penyelesaian sengketa yang memiliki banyak keuntungan, namun demikian dalam implementasinya masih banyak ditemukan kendala-kendala, antara lain :

\section{Sumber Daya Manusia}

Kendala yang dihadapi oleh Badan Pertanahan Nasional Kota Samarinda dalam hal sumber daya manusia adalah kekurangan sumber daya manusia yang menangani sengketa seperti halnya kekurangan pegawai yang berkompeten dalam menangani kasus-kasus pertanahan yang ada serta minimnya pelatihan pegawai yang bertugas sebagai mediator untuk menyelesaikan sengketa pertanahan.

\section{Sikap/attitude}

Sikap/attitude mediator yang kurang baik seperti tidak hadir tepat waktu diruang mediasi sehingga membuat para pihak yang ingin menyelesaikan sengketa secara mediasi tidak nyaman juga membuang waktu para pihak yang bersengketa. Juru ukur yang tidak dapat hadir baik pada saat pengukuran tanah seperti yang dijadwalkan sehingga menghambat jalannya mediasi. Dan juga pada saat gelar mediasi dilakukan, juru ukur tidak dapat menghadiri gelar mediasi sehingga tidak dapat menjelaskan data secara rinci. Kemudian dalam hal jangka waktu penerbitan berita acara mediasi yang lama dikarenakan notulen yang mendampingi mediator kurang jelas memahami apa saja poin-poin yang disampaikan ketika mediasi sedang digelar.

\section{Sarana dan Prasarana}

Hal yang paling umum kendala dalam hal sarana dan prasarana adalah minimnya fasilitas untuk memudahkan penyelesaian sengketa oleh Badan Pertanahan Nasional Kota Samarinda. Fasilitas seperti kendaraan untuk mencapai lokasi tanah yang sedang dipersengketakan kedua belah pihak. 


\section{Kekurangan Saksi Terkait Riwayat/Tentang Kronologis Tanah \\ Kurangnya saksi yang dihadirkan} didalam gelar mediasi, yaitu saksi terkait objek tanah yang disengketakan seperti saksi penjual atau pembeli tanah dan dari pihak instansi terkait (RT, Lurah dan Camat) yang tidak dapat hadir dan atau tidak memiliki data serta saksi batas tanah yang tidak dapat melengkapi riwayat atau kronologis tanah sengketa yang berada dibatas tanah mereka.

\section{Karakter Para Pihak Yang \\ Bersengketa}

Karena sengketa tanah adalah permasalahan dari kedua belah pihak sehingga harus menempuh suatu jalur untuk menyelesaikan permasalahan tersebut, akan tetapi tidak selalu para pihak ingin mengedepankan kepentingan bersama. Sering terjadi dimana para pihak hanya mementingkan diri sendiri untuk mendapatkan keuntungan baginya. Hal ini tentu sangat menghambat jalur mediasi yang bertujuan untuk mencapai win-win solution. Sering sekali akibat perbedaan pendapat dari kedua belah pihak tanpa adanya keinginan untuk menyelesaikan masalah pertanahan secara bersama-sama akhirnya membuat mediasi tidak berhasil atau tidak berjalan sebagaimana yang diinginkan yaitu mencapai keputusan yang mufakat.

\section{Kurang Populernya Badan Pertanahan Nasional (BPN) Sebagai Wadah Penyelesaian Sengketa Pertanahan Oleh Masyarakat Kota Samarinda}

Masyarakat Kota Samarinda yang kurang memahami alternatif penyelesaian sengketa terlebih penyelesaian sengketa pertanahan kebanyakan hanya atau langsung menempuh jalur peradilan yang berujung kepada gugatan. Kurangnya kesadaran masyarakat inilah yang menyebabkan kurang diperhatikannya alternatif penyelesaian sengketa oleh Badan Pertanahan Nasional Kota Samarinda. Terlebih anggapan dari masyarakat Kota Samarinda tentang keputusan mediasi yang kurang efisien dikarenakan keputusan mediasi yang tidak mempunyai kekuatan eksekutorial sehingga masyarakat lebih memilih penyelesaian sengketa tanah melalui peradilan.

\section{PENUTUP \\ KESIMPULAN DAN SARAN}

Berdasarkan hasil pembahasan mengenai mekanisme penyelesaian sengketa pertanahan yang dilakukan Badan Pertanahan Nasional Kota Samarinda ditinjau berdasarkan Peraturan Kepala Badan Pertanahan Nasional Republik Indonesia Nomor 3 Tahun 2011 Tentang Pengelolaan Pengkajian dan Penanganan Kasus Pertanahan, maka penulis menyimpulkan bahwa yang merupakan hasil akhir dalam penelitian ini adalah sebagai berikut :

1. Bahwa mekanisme penyelesaian sengketa yang dilakukan oleh Kantor Badan Pertanahan Nasional Kota Samarinda melalui mediasi terbagi menjadi beberapa tahap yaitu tahap pertama adanya pengaduan, tahap kedua menelaah pengaduan para pihak yang bersengketa, tahap ketiga undangan atau pemanggilan, tahap keempat upaya mediasi dan tahap kelima formalisasi kesepakatan penyelesaian sengketa.

2. Kendala Badan Pertanahan Nasional Kota Samarinda dalam menyelesaikan sengketa pertanahan adalah terkait sumber daya manusia, sikap/attitude, sarana dan prasarana, kekurangan saksi terkait riwayat/tentang kronologis tanah, karakter para pihak yang bersengketa, dan kurang populernya Badan Pertanahan Nasional (BPN) sebagai wadah penyelesaian sengketa pertanahan oleh masyarakat Kota Samarinda. 


\section{DAFTAR PUSTAKA}

Buku Atau Literatur

Amiruddin, Zainal Asikin, Pengantar Metode Penelitian Hukum, Raja Grafindo Persada, Jakarta, 2006

Ali Achmad Chomzah, Seri Hukum Pertanahan III, Penyelesaian Hak Atas Tanah dan Seri Hukum Pertanahan IV Pengadaan Tanah Instansi Pemerintah, Jakarta, 2003

Bambang Sunggono, Metode Penelitian Hukum, Raja Grafindo Persada, Jakarta, 2012

Bernhard Limbong, Konflik Pertanahan, Margaretha Pustaka, Jakarta, 2012

Frans Hendra Winarta, Hukum Penyelesaian Sengketa, Cet. 1, Sinar Grafika, Jakarta, 2012

Maria S.W. Soemardjono, Mediasi Sengketa Tanah Potensi Penerapan Alternatif Penyelesaian Sengketa (ADR) Di Bidang Pertanahan, Buku Kompas, Jakarta, 2008

M. Syamsudin, Operasional Penelitian Hukum, Raja Pers, Jakarta, Cet I, 2007

Muchsan, Sistem Pengawasan Terhadap Perbuatan Aparat Pemerintah dan Peradilan Tata Usaha DiIndonesia, Liberty, Yogyakarta, 2000

Muchsin, Imam Koeswahyono, Soimin, Hukum Agraria Indonesia Dalam Perspektif Sejarah, Refika Aditama, Bandung, 2010

Rachmadi Usman, Mediasi Di Pengadilan Dalam Teori dan Praktik, Cet.1, Sinar Grafika, Jakarta, 2012

Rinto Manulang, Segalanya Hal Tentang Tanah, Rumah Dan Perizinannya,Buku Pintar, Yogyakarta, 2012

Sarjita, Teknik dan Strategi Penyelesaian Sengketa Pertanahan, Tugu Jogya Pustaka, Yogyakarta, 2005

Soerjono Soekanto, Pengantar Penelitian Hukum, UI Pers, Jakarta, 2010

Soerjono Soekanto, Sri Mamudji, Penelitian Hukum Normatif Suatu Tinjauan Singkat, Raja Grafindo Persada, Jakarta, 2012

Sri Soemantri, Prospek dan Pelaksanaan Arbitrase di Indonesia, Citra Aditya Bakti, Bandung, 2001
Tri Kurnia Hayati, Kamus Besar Bahasa Indonesia, Eska Media Press, 2012

Zainuddin Ali, Metode Penelitian Hukum, Sinar Grafika, Jakarta, Cet.I, 2009

\section{Peraturan Perundang-undangan}

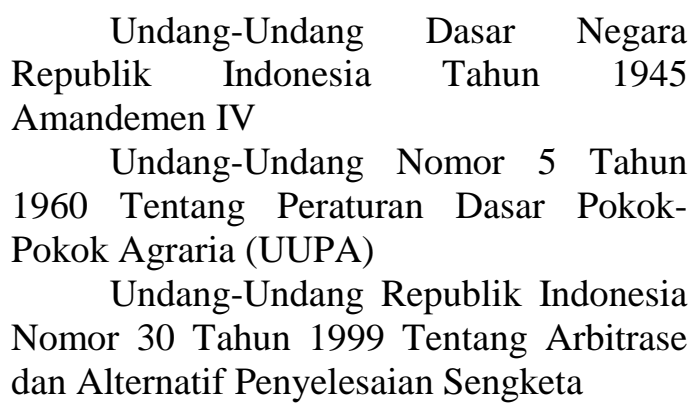

Peraturan Presiden Republik Indonesia Nomor 20 Tahun 2015 Tentang Badan Pertanahan Nasional

Peraturan Kepala Badan Pertanahan Badan Pertanahan Nasional Republik Indonesia Nomor 4 Tahun 2006 Tentang Organisasi dan Tata Kerja Kantor Wilayah Badan Pertanahan Nasional dan Kantor Pertanahan

Peraturan Kepala Badan Pertanahan Nasional Republik Indonesia Nomor 3 Tahun 2011 Tentang Pengelolaan Pengkajian dan Penanganan Kasus Pertanahan

Keputusan Kepala Badan Pertanahan Nasional Republik Indonesian Nomor 34 Tahun 2007 Tentang Petunjuk Teknis Penanganan dan Penyelesaian Permasalahan Pertanahan

\section{Internet}

http://www.bpn.go.id/Program/Penanganan -Kasus-Pertanahan diakses 1 Agustus, 2016

http://eprints.uny.ac.id/22029/4/4.BAB\%20 II.pdf diakses 2 Agustus, 2016

https://core.ac.uk/download/files/379/11723 275.pdf diakses 31 Juli, 2016

http://lib.unnes.ac.id/18409/1/8150408062. pdf diakses 31 Juli, 2016

Tesis

Herwandi, Peran Kantor Pertanahan Dalam Rangka Penyelesaian Sengketa Tanah Secara Mediasi Di Kantor Pertanahan Jakarta Utara, 
Tesis, Program Magister

Kenotariatan Universitas

Diponegoro, Semarang , 2010 